\title{
Kuluttajan metamorfoosi
}

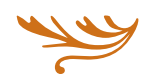

JUHLAKAUSINA IHMISET ovat kulutuskäyttäytymisensä kliimaksissa. Esimerkiksi joulun jälkeen roskikset pullistelivat "ostaostaosta"-katalookeja, rytättyjä lahjapapereita ja asunnot tavaraa. Maapallon ylikulutuksen päivä ja "älä osta mitään”-päivä ehtivät tulla ja mennä saamatta aikaan merkittävää tykytystä kuluttajan sydänalassa.

Ilmastonmuutos on yhteiskuntamme lähes mahdottomalta tuntuva haaste, samoin käytössä olevien resurssien niukkeneminen. Kun maapallon kestokyvyn rajat vilkkuvat punaisella, tulisi jotain tapahtua. Ville Lehto pohtii hiljattain ilmestyneessä kirjassaan tuo ta muutosta ja sopeutumistamme niukkuuden maailmaan. Roope Mokka ja Aleksi Neuvonen toteavat 2009 toimittamassaan pamfletissa Olimme kuluttajia, että muutoksen tuloksena ei ole kuluttajan kuolema, vaan totaalinen muodonmuutos.

José Manuel Asun ja Matthias Finger haastoivat jo vuosia sitten aikuiskasvattajia kauppojen hyllyjen väliin. Aikuiskoulutuksen tulisi tarjota oppimisen eväitä ihmisille, jotka päivittäin painivat eettisten kysymysten kanssa tehdessään kulutuspäätöksiään ja valintojaan. Heidän mukaansa sivistysteot tehdään jatkossakin kauppojen hyllyjen välissä. Se on osa muodonmuutosta, metamorfoosia.

Asunin ja Fingerin mielestä ympäristötietoinen sivistystoiminta olisi välttämätöntä myös aikuiskasvatukselle itselleen, sen oman tulevaisuuden vuoksi. 


\section{TUOTTAMISEN SUUNTA}

PITÄISIKIN OLLA

VÄHEMMÄST ̈̈̈ VÄHEMMÄN.

\section{SIVISTÄVIÄ HUVEJA}

Arto Salonen puhuu ekososiaalisesta sivistyksestä, jonka tavoitteena on hyvä elämä kaikille ja aina. Hänen mukaansa sivistynyt ihminen kysyy, riittääkö elämän tarkoitukseksi materialistisen vaurauden maksimointi, joka perustuu luonnonvarojen hyödyntämiseen, vai olisiko ensisijaisesti tavoiteltava jokaiseen päivään merkitystä, mielekkyyttä, syvyyttä ja iloa?

Kuluttamisestakin toki saa iloa ja nautintoa. Se, joka väittää vastaan, huijaa. Tästä nautinnosta syntyi sukupolveni aikana se kuluttamisen elämänmuoto, joka nyt uhkaa tuota samaista nautintoa ja maapallon tulevaisuutta. Ostamisesta ja omistamisesta syntyvä ilo on valitettavan lyhyt, eikä onnellisuuden määräkään tällä pallolla ole tavaroiden myötä juuri kasvanut. Olisiko mahdollista muuttaa suuntaa?

Missä luuraavat aikuiskoulutus ja vapaa sivistystyö? Ja mitä niiden oikein pitäisi tehdä? Muodonmuutos ei ole helppo prosessi, me kun elämme tavarataivaassa. Shoppailu netissä on helppoa ja kaupoissa hauskaa. Haluja syntyy jatkuvasti lisää. Muutos on kuitenkin mahdollista, jos ymmärrämme maapallon rajallisuuden.

Aikuiskoulutuksessa on usein ajateltu, että kestävän kuluttamisen eväät saadaan ennen aikuisikää. Nyt ymmärretään, että isoon muodonmuutokseen tarvitaan kaikkia oppimisen muotoja ja elämän vaiheita. Vapaan sivistystyön rooli ei ole mitätön, jos ajatellaan, että yli miljoona suomalaista on vuosittain sen vaikutuspiirissä.

Ilon tuottamiseen, merkityksen ja tarkoituksen löytämiseen ja sen myötä kuluttajan muodonmuutokseen mahtuu monta keinoa ja mahdollisuutta. Professori Petri Salo puhuu "sivistävistä huveista”, onnellisuutta lisäävistä toimista ja harrastuksista, joissa vapaa sivistystyö ja aikuiskoulutus ovat omimmillaan. Niitä voivat olla kuorolaulu, vatsatanssin pyörteet, ilmiöoppiminen Itämeriprojektissa tai vaikkapa muistojen kollaasin rakentaminen.

\section{VASTAVIRRASTA ILMIÖ}

Mokan ja Neuvosen pamfletti havainnollistaa mahdollisuuksiamme nähdä erilaisia kuluttamisen tulevaisuuksia. Vaihtoehtoiset skenaariot avaavat näkymiä siitä, millaista tulevaisuutta haluamme ja millaiseen metamorfoosiin haluamme kiinnittyä.

Identiteetti, persoona, trendit ja brändit riipivät kuluttajan orvaskettä syvältä tässä muodonmuutoksessa. Siksipä vastavirtakin on noussut ilmiöksi. Kun nuoret suunnittelijat puhuvat rohkeasti eettisistä arvoista ja ekologisuudesta, ajattelen, että peli ei ole menetetty. Oivaltavat ratkaisut ovat tuoneet jäte- ja kierrätysmateriaalit sekä vaihtoehtoiset raaka-aineet uudelle tasolle, salonkikelpoisiksi ja haluttaviksi.

Tuottamisen suunta pitäisikin olla vähemmästä vähemmän, mutta toisella tavalla tehtynä. Kun vähemmästä tehdään vähempää, kokeilut luovat uudenlaista. Vaikka niin, että tavallisesti jätteisiin joutuvista kalannahkoista syntyy upeita laukkuja tai puusta silmälasikehyksiä. Mahdollisuuksia riittää.

Syyllisyystaakka on kulutuskasvatuksen viheliäinen riippakivi. Kuluttaminen on meissä syvällä, ja tavaroiden kerääminen on meihin sisäänkoodattu. Syyllistyessämme panemme helposti silmät ja korvat kiinni. Metamorfoosi pysähtyy.

Siksi olisi tarpeen oppia uusia keinoja ymmärtää kuluttamista ja käyttäytymistämme. Kuluttaminen on sosiaalista kieltä. Kulutustapamme, käyttämämme tuotemerkit ja omaksumamme tyylit paljastavat kaikille, keitä olemme ja mihin kuulumme. Haemme yksilöllisyyttä kielellä, jonka merkit jokainen tunnistaa. Aikuiskoulutus ja vapaa sivistystyö voisivat olla avaamassa tätä sosiaalisen kielen ymmärrystä. Tuotemerkkien ja kalleuden korostamisen sijaan se voisi opettaa toisenlaista kieltä, arvokkuuden ja välittämisen kieltä.

\section{MONIÄÄNISYYTTÄ MUODONMUUTOKSEEN}

Tarvitsemme skenaarioita, mahdollisuuksia pohtia ja kyseenalaistaa sekä käsitellä asioita yhdessä niin, että oikeita vastauksia ei ole - vain hyviä kysymyksiä. Tällaisina asenteiden selkeyttämisen, tietojen ja elämäntavan oppimispaikkoina voivat vapaan sivistystyön oppilaitokset tehdä itsensä enemmän kuin tarpeellisiksi. 
Suomen kestävän kehityksen toimikunta on kuluneen syksyn aikana valmistellut Kestävän kehityksen yhteiskuntasitoumusta. Vapaa Sivistystyö ry. asetti siihen visionsa seuraavasti:

"Kestävän tulevaisuuden koulut ja oppilaitokset toimivat esimerkkinä kestävästä elämäntavasta. $\mathrm{Ne}$ ovat paikallisesti, alueellisesti ja koko Suomen tasolla solmukohtia ja aloitteentekijöitä, jotka verkottuvat muiden yhteiskunnan toimijoiden kanssa tavoitteena oppimisen ja kulttuurisen muutoksen edistäminen kohti kestävän tulevaisuuden yhteiskuntaa."

Halu muutokseen on olemassa. Teot syntyvät merkityksistä ja toisten kanssa oppimisesta. Ne syntyvät myös suunnasta ja valinnasta.

Dissonanssi eli moniäänisyys mahdollistaa muodonmuutoksen. Yksinkertaisten oppien sijaan voimme oppia juuri moninaisuudesta. Sen seurauksena ratkaisuja ryhdytään etsimään porukalla. Kun kansalaiset ovat näyttäneet muutoksen välttämättömyyden, mukaan tulevat myös poliitikot ja hallitukset. Meistä kaikista on kiinni, onnistuuko muodonmuutos demokratian keinoin.

Kuluttamisen tulevaisuus ei ole etukäteen määritetty, vaan sitä tulee koko ajan yhdessä muokata ja aktiivisesti rakentaa. Rajallisen maapallon kuluttajan muodonmuutos alkaa tämän oivaltamisesta.

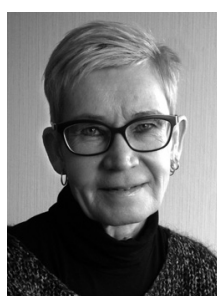

Kaisa Lindström

rehtori, koulutusasiantuntija Otavan Opisto

(Kuva: Lasse Lindström)

\section{VIITTAUKSET}

Finger, M. \& Asun, J.M. (2001). Adult Education at the Crossroads - learning Our way out. Zed Books, 7-4.

Lähde, Ville (2013). Niukkuuden maailmassa. niin ja näin -kirjat.

Mokka, Roope \& Neuvonen, Aleksi (toim.) (2009). Olimme kuluttajia. Neljä tarinaa vuodesta 2023. Helsinki: Tammi.

Salonen, Arto (2010). Kestävä kehitys globaalin ajan hyvinvointiyhteiskunnan haasteena. Helsinki: Helsingin yliopisto.

Kestävän kehityksen yhteiskuntasitoumus "Suomi, jonka haluamme 2050". Suomen kestävän kehityksen toimikunta. Hyväksytty 3.12.2013. 